\title{
Epiglottic Metastasis from a Recurrent Nasopharyngeal Carcinoma: A Rare Manifestation
}

\author{
Tekrarlayan Nazofarengeal Karsinoma bağlı Epiglotik Metastaz: Nadir Bir Belirti
}

\section{Thilaga Rajendran ${ }^{1}$, Yogesvaran Kanapaty ${ }^{1}$, Valuyeetham Kamaru Ambu ${ }^{1}$, Junalina Jaafar ${ }^{2}$}

${ }^{1}$ Department of Otorhinolaryngology, Hospital Tuanku Jaafar Seremban (Ministry of Health, Malaysia), Jalan Rasah, Seremban, Negeri Sembilan, Malaysia

2 Department of Pathology, Hospital Tuanku Jaafar Seremban (Ministry of Health, Malaysia), Jalan Rasah, Seremban, Negeri Sembilan, Malaysia

\section{ABSTRACT}

Nasopharyngeal carcinoma (NPC) is the third most common malignancy among men in Malaysia, accounting for about $8.1 \%$ of cases. This malignancy is shown to be occurring from a complex interplay between environmental, genetic and viral factors. The presence of distant metastasis affects the rate of survival in many types of malignancy. This is especially true in nasopharyngeal cancers, where there is a higher risk of distant metastases compared to other types of head and neck malignancies. We report a case of a 65-year-old man with recurrent nasopharyngeal carcinoma, presented with an unusual metastasis over the epiglottis. The patient came with complaints of hoarseness and blood-stained sputum for the past few months. On examination, he had hoarseness with an irregular, suspicious mass at the epiglottis. Endoscopic laryngeal microsurgery was done and the histopathology report confirmed a recurrent NPC of undifferentiated type. This case illustrates the diagnostic challenges faced by clinicians when approaching patients with post-NPC treatment.

Key Words: Epiglottic metastasis, nasopharyngeal carcinoma, rare metastasis

\section{ÖZET}

Nazofarengeal karsinom (NPC), Malezya'daki erkekler arasında en yaygın üçüncü malignite olup, vakaların yaklaşık \% 8,1'ini oluşturur. Bu malignitenin çevresel, genetik ve viral faktörler arasındaki karmaşık bir etkileşimden oluştuğu gösterilmiştir. Uzak metastaz varlığı birçok malignitede sağkalım oranını etkiler. Bu özellikle diğer baş ve boyun malignitelerine göre daha yüksek metastaz riski taşıyan nazofarenks kanserlerinde geçerlidir. Burada, tekrarlayan nazofarengeal karsinomu olan ve epiglot üzerinde olağandışı bir metastaz ile başvuran 65 yaşındaki bir erkek olguyu sunduk. Hasta, son birkaç aydır ses kısıklığı ve kanlı balgam yakınmalarıyla geldi. Muayenede, epiglotta düzensiz, şüpheli bir kitle ile ses kısıklığı yaşadı. Endoskopik laringeal mikrocerrahi yapıldı ve histopatoloji raporu farklılaşmamış tipte tekrarlayan NPC'yi doğruladı. Bu vaka, NPC sonrası tedavi gören hastalara yaklaşırken klinisyenler tarafından karşılaşılan tanı zorluklarını göstermektedir.

Anahtar Sözcükler: Epiglotik metastaz, nazofarengeal karsinom, nadir metastaz

Geliş Tarihi: 02.10.2018

Kabul Tarihi: 08.01.2019

\section{INTRODUCTION}

Being the third most common malignancy among men in Malaysia, nasopharyngeal cancers (NPC) account for about $8.1 \%$ of cases(1). It is also the most often occurring neoplasm in otorhinolaryngology setting. NPC most commonly occurs in the posterolateral nasopharynx or Fossa of Rosenmüller. NPC has seen to be occurring from a complex interplay between environmental, genetic and viral factors. In a study done in Taiwan, the correlation levels of dietary nitrosamine and the risk of developing NPC were proven. People who consume food rich in nitrosamine during their childhood were found to have 2.6 fold higher risk of getting NPC(2). Prolonged cigarette smoking, possible exposure to formaldehyde and wood dust, and habits of betel nut chewing are also regarded as important contributing etiologies to NPC.

Genetic cause is also contributive as NPC is very rampant in certain parts of China, specifically in Guangdong, comprising about $18 \%$ of all malignancies in the nation(3). In addition, infection with Epstein-Barr virus (EBV) had been shown to have a strong link to NPC. A study done have proven that the DNA of EBV virus was detectable in about $96 \%$ of patients with non-keratinizing NPC, compared with only $7 \%$ in controls(4).
The usual sites of metastasis for NPC are lymph nodes, liver, bones and lungs, whilst the lungs being the most common site. On the other hand, the most frequent organ of metastasis in the autopsy patients is the liver. Bone metastases have the highest incidence of the undifferentiated type of $\mathrm{NPC}(5)$. Thus, evidence of distant metastasis affects the rate of survival in many types of malignancy. This is more than evident in nasopharyngeal malignancies, as there is a greater risk of distant metastases in comparison to other types of head and neck cancers. The occurrence rate of isolated distant metastasis is on a rise, about $18 \%$, worldwide. The risk becomes augmented with the staging of cancer, whereby a stage IVB NPC can lead to a $47 \%$ higher tendency for a distant metastasis. Thus, a locoregional treatment for a locally advanced disease is clearly insufficient(6).

We report a case of a 65-year-old man with recurrent nasopharyngeal carcinoma, whom presented with an unusual metastasis over the epiglottis.

\section{CASE REPORT}

A 65-year old man with underlying hypertension was diagnosed with nasopharyngeal carcinoma (T1N2CM0) in 2006. 
He had completed concurrent chemoradiotherapy in that particular year. The patient, later, went into a remission and was well for 8 years. In 2014, he had recurrent NPC, without any distant metastasis and completed another concurrent chemoradiotherapy session. The patient then presented in the year 2016 with complaints of hoarseness and blood-stained sputum for the past few months. On examination, he had hoarseness. No neck mass was palpable. Flexible nasopharyngolaryngoscope revealed an irregular mass at the left laryngeal surface of epiglottis(Figure 1).

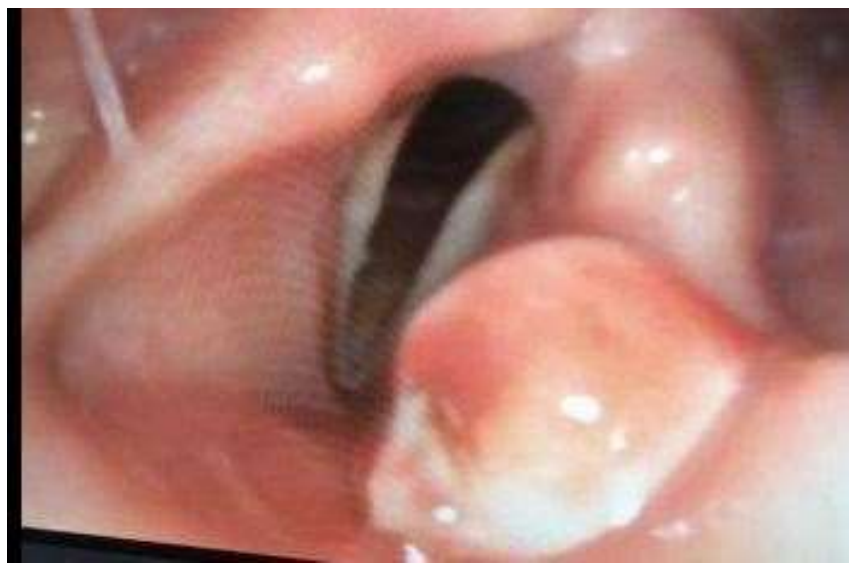

Figure 1 Flexible scope showing an irregular mass at the left laryngeal surface of epiglottis

Bilateral fossa of rosenmuller (FOR) were clear, with minimal crusting at the nasopharynx. The patient was scheduled for an endoscopic laryngeal microsurgery under general anesthesia, with the mass completely removed. Histopathology findings from the epiglottic mass confirmed a recurrent NPC, an undifferentiated type. The malignant epithelial cells exhibited large, pleomorphic hyperchromatic nuclei with prominent nucleoli. Also, immunohistochemistry staining proved strong positivity toward pan CK and p63 markers which are useful markers to distinguish NPC subtypes(Figure 2a, 2b \& 2c).

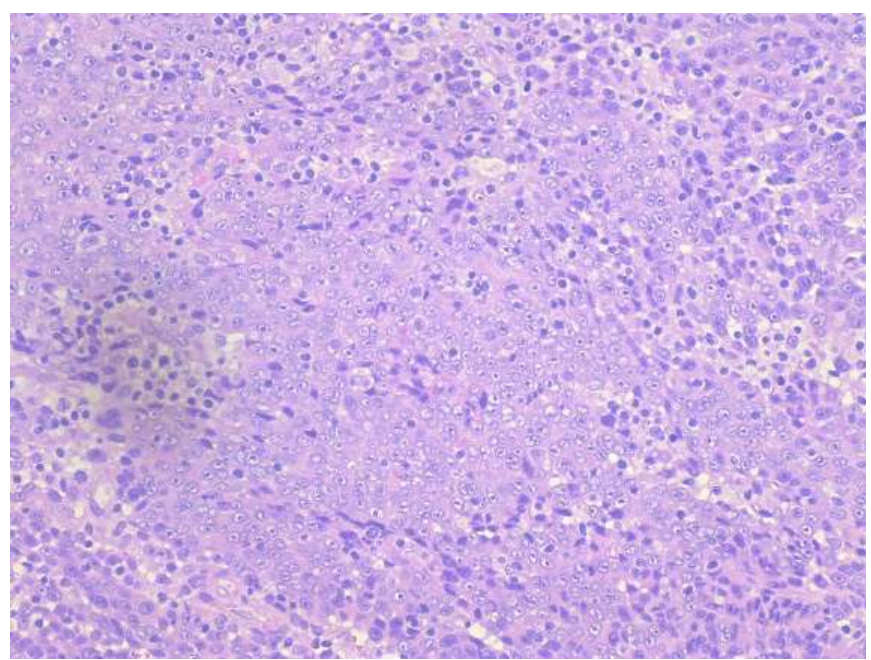

Figure 2a The malignant cells are arranged in solid sheet pattern surrounded by an inflammed stroma

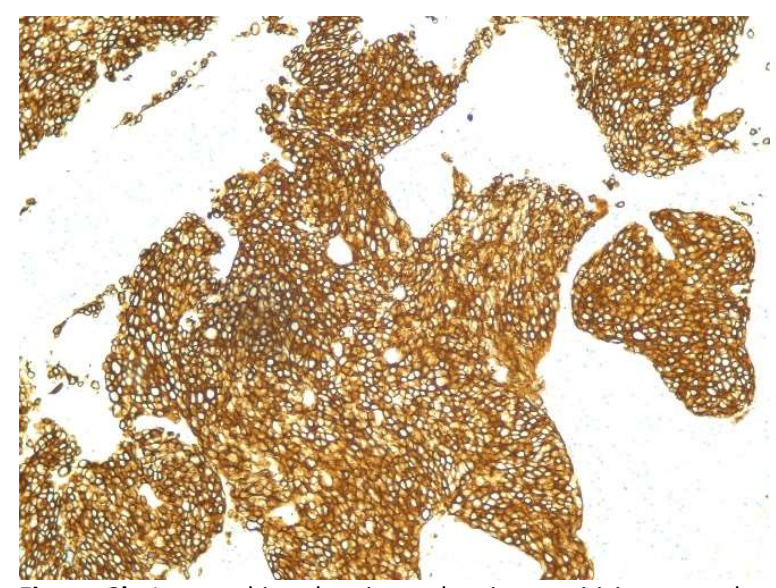

Figure $\mathbf{2 b}$ Immunohistochemistry showing positivity towards pan CK marker

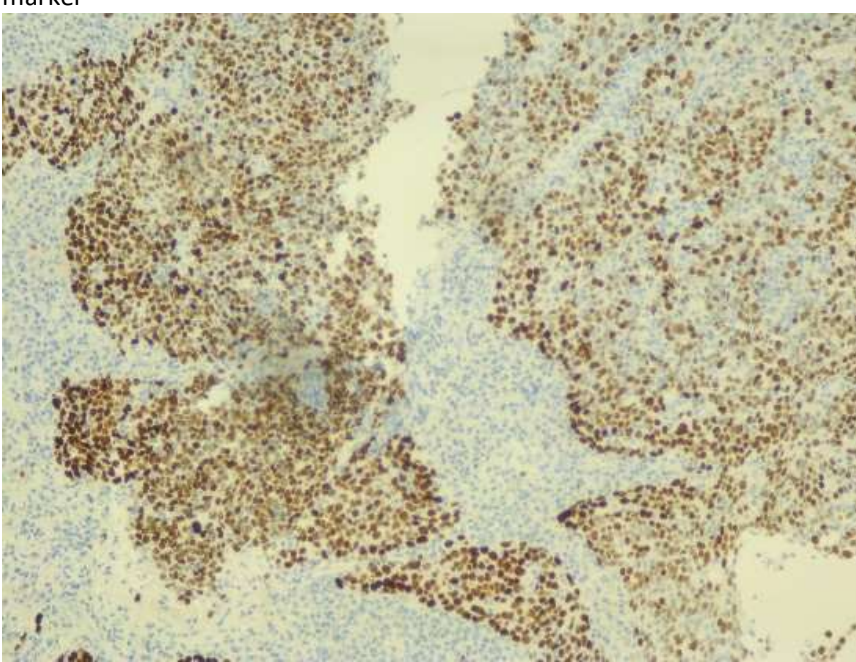

Figure 2c Immunohistochemistry showing positivity towards P63 marker

Computed tomography imaging showed the presence of lymphadenopathies in right level IB and V of the neck, with miliary lung nodules likely metastases(Figure $3 \& 4$ ). A bone scan performed showed evidence of bone metastasis in the right temporal bone. After the endoscopic removal of the epiglottis mass, the patient was then referred to an oncology team. Regular follow-ups are arranged on monthly basis at our centre. About two months post-operatively, re-appearance of the growth at the samelocation had been detected during the follow-ups. But, the first complaint of blood-stained sputum has resolved. Subsequently, during the oncological follow-ups, patient was planned for chemotherapy but he refused the treatment. 


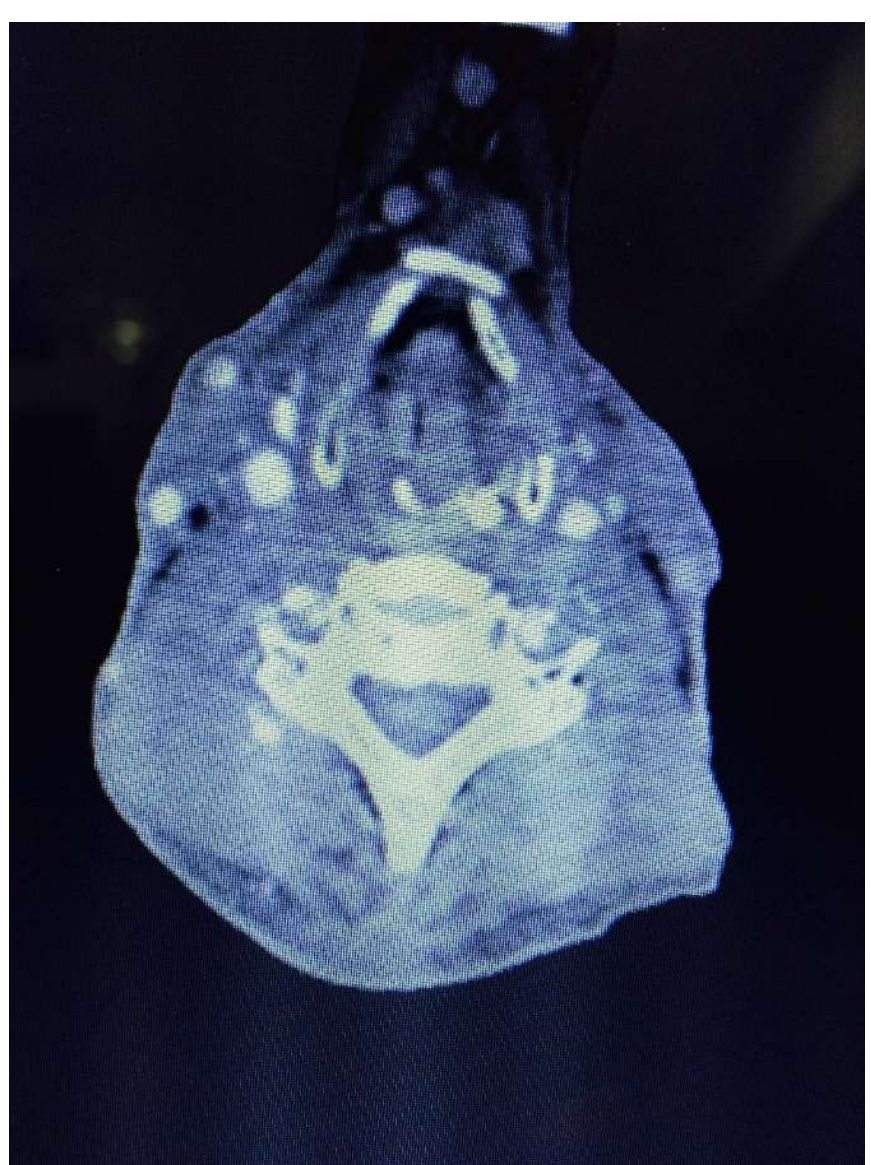

Figure 3 Computed tomography imaging showing the presence of lymphadenopathies in right level IB and V of the neck

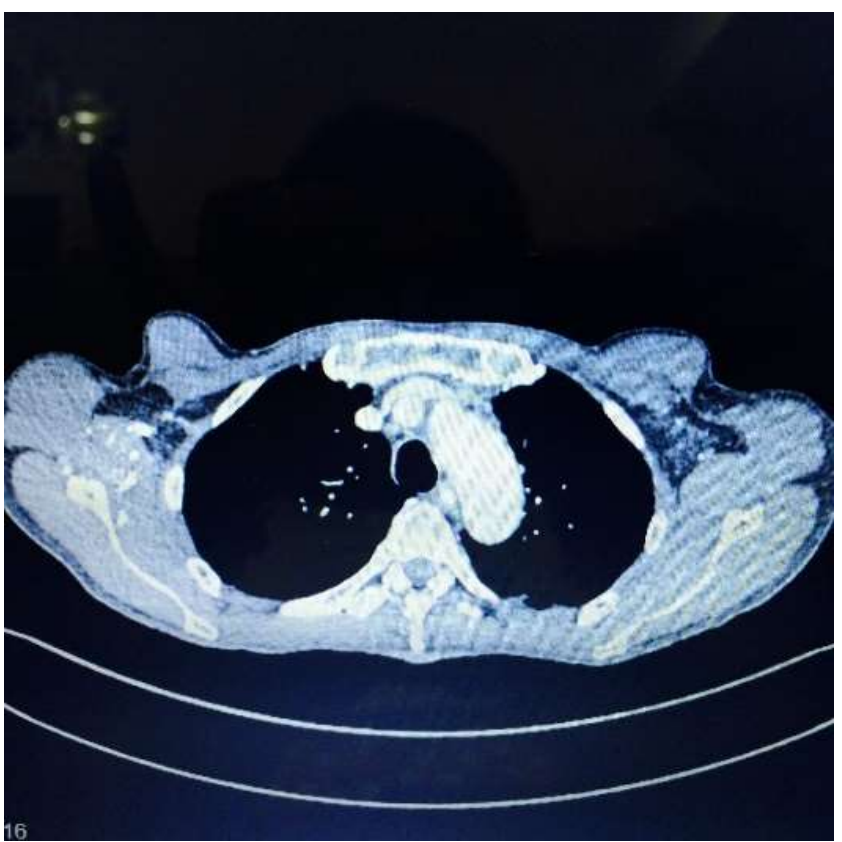

Figure 4 Computed tomography imaging showing miliary lung nodules

\section{DISCUSSION}

In essence, transmission of NPC can either be local, via lymphatic spread or by distant metastases. Anterior spread causes choana and nasal cavity blockage, while the inferior spread is towards the oropharynx and hypopharynx.
A lateral spread involves the parapharyngeal space and infratemporal fossa through the sinus of Morgagni, while an upward extension is towards the intracranial structures. Although NPC is a commonly encountered diagnosis, a distant metastasis in epiglottis is a rare one. To the best of our knowledge, there have been no similar cases found in English literature so far. Some of the rare sites of distant metastasis reported in the literature involve the dura, skin, parotid and thyroid glands, ribs and even the spleen and colon. In this case, the likely route of spread to the epiglottis is via hematogenous way. The prevalence of distant metastases are due to various factors like the first staging of the malignancy (Tumour and Nodal stages), site of a primary tumour and also the absence or presence of regional control superior to the clavicle. The risks of developing distant metastases are also raised in advanced nodal diseases, especially when a tumour extends into the jugular vein or a prominent soft tissue disease in the neck(7). This is true as in this case, as the patient had the initial staging of T1N2CMO. Microscopically, evidence of recurrent NPC was made due to the intact epidermis seen. Infiltration of a tumour from inside the stroma has been found. This is in contra to the occurrence of laryngeal cancer at the discussed site, as a laryngeal tumour usually infiltrates the stroma from the outside.

Do synchronous or metachronous tumors arise in NPC? Though the incidence such cases are quite low, literatures have revealed the development of synchronous tumors in head and neck region and the aerodigestive tract(8). This development is called as 'field cancerization' (9). According to a study conducted in Taiwan, about 3\% of patients with NPC have been diagnosed with a second cancer. The aerodigestive system, skin, lymphoproliferative malignancies, and connective tissue are the most frequent sites of second cancer(10).

In contrast to other squamous cell carcinomas of the head and neck, it is easier to distinguish NPC from second primary cancers because of the distinct histology, of the most occurring WHO Type III (undifferentiated carcinoma).

\section{CONCLUSION}

The sites of metastasis can occur relatively distant from the primary lesion, even after a period of remission. Though benign epiglottis masses are common, one should bear in mind that the rare malignant lesions at epiglottis do occur. Thus, targeted investigations during follow-ups are important in preventing recurrent malignancies.

\section{Conflict of interest}

No conflict of interest was declared by the authors.

\section{REFERENCES}

1. Cancer Statistics, Data and Figure

2. Ward, M. H., Pan, W.-H., Cheng, Y.-J., Li, F.-H., Brinton, L. A. et.al. Dietary exposure to nitrite and nitrosamines and risk of nasopharyngeal carcinoma in Taiwan. Int. J. Cancer 2000; 86: 603-9.

3. Chang ET, Adami H,The Enigmatic Epidemiology of Nasopharyngeal Carcinoma, Cancer Epidemiol Biomarkers Prev. 2006;15: 1765-77.

4. Lo KW, Chung GT, To KF, Deciphering the molecular genetic basis of NPC through molecular, cytogenetic, and epigenetic approaches. Semin Cancer Biol. 2012; 22:79-86.

5. Nasopharyngeal Cancer Clinical Presentation: History, Physical, Causes [Internet]. Emedicine.medscape.com. 2017 [cited 11 February 2017]. Available from: http://emedicine.medscape.com/article/988165-clinical\#b5 6. Sawali, Mohd Razif Mohamad Yunus, Ong Cheng Ai, Primuharsa Putra Sabir Husin Athar, Cutaneous Metastases from Nasopharyngeal Carcinoma: A Rare Manifestation, Philippine Journal Of Otolaryngology-Head And Neck Surgery Vol. 25 No. 2 July - December 2010

7. Lahuri Y, Mohamad I, Hashim H. Nasopharyngeal carcinoma with metastases to colon, ScienceDirect. 2015; 16: 201-4.

8. Rennemo E, Zätterström U, Boysen M: Synchronous second primary tumors in 2016 head and neck cancer patients: Role of symptom-directed panendoscopy. Laryngoscope. 2011; 121: 304-9.

9. Slaughter DP, Southwick HW, Smejkal W: Field cancerization in oral stratified squamous epithelium clinical implications of multicentric origin. Cancer. 1953; 6: 963-8.

10. Chen M-C, Feng I-J, Lu C-H, Chen C-C, Lin J-T, Huang S-H, Lee K-D: The incidence and risk of second primary cancers in patients with nasopharyngeal carcinoma: a population-based study in Taiwan over a 25 -year period (19792003). Annals of Oncology. 2008; 19: 1180-6 